\title{
Electrochemical and Spectroscopic Investigation of Ethanol Oxidation on Au/Pt Nanocomposite
}

\author{
Xingyue Wei ${ }^{*}$ Xingmin Wang and Lin Zhuo \\ College of Environment and Resources, Chongqing Technology and Business University, Chongqing \\ 400067, P.R. China \\ *E-mail: xingyuewei_cq@yeah.net
}

doi: $10.20964 / 2017.04 .53$

Received: 28 January 2017 / Accepted: 19 February 2017 / Published: 12 March 2017

\begin{abstract}
The synthesis of gold/Platinum ( $\mathrm{Au} / \mathrm{Pt}$ ) bimetallic nanodendrites was accomplished by a seeded growth method utilizing prefabricated $\mathrm{Au}$ nanodendrites as seeds and ascorbic acid as a reductive agent. Through voltammertric characterization, it showed that Au on the step acted as a catalyst for the ethanol oxidation. In order to investigated the effect of Au ratio in the mechanism, FTIR experiments were conducted with the use of normal and isotopically labelled ethanol.
\end{abstract}

Keywords: Ethanol oxidation; Nanodendrites; Electrochemical study; FTIR; Alkaline direct ethanol fuel cells

\section{FULL TEXT}

(C) 2017 The Authors. Published by ESG (www.electrochemsci.org). This article is an open access article distributed under the terms and conditions of the Creative Commons Attribution license (http://creativecommons.org/licenses/by/4.0/). 